\title{
ANALISIS PENGARUH INFLASI, NILAI TUKAR RUPIAH, DAN SUKU BUNGA SBI TERHADAP PERGERAKAN INDEKS HARGA SAHAM GABUNGAN DI BURSA EFEK INDONESIA
}

\author{
NURWANI \\ Dosen Fakultas Ekonomi Universitas Muhammadiyah Sumatera Utara \\ email : wani_01@ymail.com
}

\begin{abstract}
The purpose of this research was to analyze the effect Inflation, Exchange rates of Rupiah, Interest rate of Indonesia Certificates on the movement of Composite Stock Price Index (CSPI) in Indonesia Stock Exchange. The population of this research was secondary data triwulan period March 2007-March 2015. Data was processed through ain the first inflation had influence negative and no significant on Composite Stock Price Index. The second showed that Exchange rates of Rupiah had influence positive and significant on Composite Stock Price Index. The third showed Interest rate of Indonesia Certificate had influence negative and significant on Composite Stock Price Index. The fourth result of this research showed Inflation, Exchange rates of Rupiah, Interest rate of Indonesia Certificates had influence and significant on Composite Stock Price Index simultaneously.
\end{abstract}

Keywords : Inflation, Exchange rates of Rupiah, Interest rate of Indonesia Certificates, and Composite Stock Price Index (CSPI).

\section{A. PENDAHULUAN}

Investasi melalui pasar modal merupakan hal yang paling diminati oleh setiap negara, terutama mengingat perannya yang strategis bagi penguatan ketahanan ekonomi suatu negara. Jika sebuah negara menginginkan investasi bertahan lama di negerinya, pemerintah harus menjaga kondisi politik yang stabil, nilai mata uang yang stabil, dan menjaga pertumbuhan ekonomi (Samsul, 2015: 2). Pertumbuhan investasi dari suatu negara akan dipengaruhi oleh pertumbuhan ekonomi negara tersebut. Semakin baik tingkat perekonomian suatu negara, maka semakin baik pula tingkat kemakmuran penduduknya. Tingkat kemakmuran yang lebih tinggi ini umumnya ditandai dengan adanya kenaikkan tingkat pendapatan masyarakatnya.

Dengan adanya tingkat pendapatan tersebut, maka akan semakin banyak orang yang memiliki kelebihan dana yang dapat dimanfaatkan untuk disimpan dalam bentuk tabungan atau diinvestasikan dalam bentuk surat-surat berharga yang diperdagangkan dalam pasar modal dengan harapan memperoleh imbalan (return). Dalam menjalankan fungsi ekonomi, pasar modal menyediakan fasilitas untuk memindahkan dana dari pihak yang memiliki kelebihan dana (lenders) kepada pihak yang membutuhkan dana (borrower) (Situmorang, 2008: 4).

Pasar yang sedang bergairah atau terjadi transaksi yang aktif, ditunjukkan dengan indeks harga saham gabungan yang mengalami kenaikkan. Kondisi inilah yang biasanya menunjukkan keadaan yang diinginkan. Keadaan pasar yang lesu ditunjukkan dengan indeks harga saham gabungan yang mengalami penurunan. Indeks harga saham 
merupakan petunjuk masa depan ekonomi suatu negara. Berbagai media memuat berita paling aktual, tidak ketinggalan juga akan memuat berita mengenai pergerakan indeks saham, khususnya Indeks Harga Saham Gabungan (IHSG) pada hari perdagangan terakhir. Indeks harga saham gabungan akan menunjukkan pergerakan harga saham secara umum yang tercatat di Bursa Efek Indonesia.

Saat terjadi krisis finansial global yang berawal dari Amerika Serikat tahun 2008 dan krisis finansial Eropa tahun 2011 mempunyai pengaruh yang negatif terhadap kegiatan pasar modal di berbagai negara. Di pasar modal Indonesia saat terjadi krisis finansial global 2008 indeks harga saham gabungan mengalami penurunan drastis hingga mencapai angka 1355.

Inflasi merupakan gejala ekonomi yang tidak hanya menjadi perhatian bagi masyarakat umum, tetapi juga menjadi perhatian bagi dunia usaha, bank sentral, dan pemerintah. Bagi dunia usaha, inflasi akan memberikan dampak negatif jika peningkatan biaya produksi lebih tinggi dari peningkatan harga yang dapat dinikmati oleh perusahaan sehingga menurunkan keuntungan yang dihasilkan perusahaan.

Perusahaan-perusahaan yang aktif melakukan kegiatan ekspor dan impor tentu berharap agar kegiatannya berjalan dengan lancar. Salah satu faktor yang melancarkan kegiatan ekspor dan impor tersebut adalah adanya mata uang sebagai alat transaksi. Salah satu mata uang yang umum digunakan dalam perdagangan internasional adalah dollar Amerika Serikat. Bagi perusahaan-perusahaan yang aktif melakukan kegiatan ekspor dan impor kestabilan nilai rupiah terhadap mata uang asing seperti dollar Amerika Serikat menjadi hal yang penting. Sebab ketika nilai rupiah terdepresiasi atau melemah terhadap dollar Amerika Serikat, hal ini akan mengakibatkan barang-barang impor menjadi mahal. Apabila sebagian besar bahan baku perusahaan menggunakan bahan impor, secara otomatis ini akan mengakibatkan kenaikan biaya produksi. Kenaikan biaya produksi ini tentunya akan mengurangi tingkat keuntungan perusahaan. Turunnya tingkat keuntungan perusahaan tentu akan mempengaruhi minat beli investor terhadap saham perusahaan yang bersangkutan. Secara umum, hal ini akan mendorong penurunan indeks harga saham gabungan.

Saat ini Bank Indonesia menggunakan tingkat suku bunga SBI sebagai salah satu instrumen untuk mengendalikan inflasi. Apabila inflasi dirasakan cukup tinggi maka Bank Indonesia akan menaikkan tingkat suku bunga SBI untuk meredam kenaikan inflasi. Hal ini sebagai upaya untuk menarik minat masyarakat menabung di bank. Akibatnya investasi khususnya dalam bentuk saham di pasar modal menjadi tidak menarik lagi dan investor akan mengalihkan dananya dari pasar modal ke tabungan. Pengalihan dana oleh investor dari pasar modal ke tabungan tentu akan mengakibatkan penjualan saham besar-besaran sehingga akan menyebabkan penurunan indeks harga saham gabungan.

Tingkat bunga yang tinggi akan mendorong investor untuk memilih deposito daripada membeli saham. Tingkat bunga rendah akan mendorong investor untuk membeli saham daripada menyimpan di deposito. Inflasi yang tinggi akan berakibat tingkat bunga dinaikkan, demikian juga sebaliknya. Kurs mata uang yang gejolak akan mendorong investor berInvestasi di valuta asing dan menjual sahamnya (Samsul, 2015: 12). 


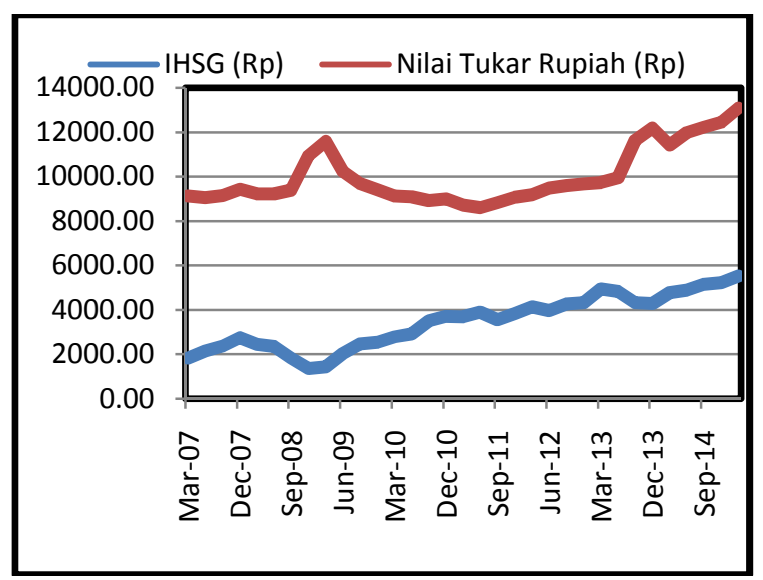

\section{Gambar 1 \\ Grafik Nilai Tukar Rupiah dan Pergerakan IHSG}

Sumber: Data Diolah (2016)

Berdasarkan gambar 1 dan 2 ketika inflasi dan suku bunga SBI mengalami kenaikan serta nilai tukar rupiah mengalami pelemahan, IHSG juga ikut mengalami kenaikan yaitu terjadi selama bulan September dan Desember 2007, Maret 2009, Maret, Juni dan Desember 2010, Desember 2011, Maret, September dan Desember 2012, Maret 2013, Juni, September dan Desember 2014 serta Maret 2015. Ketika inflasi dan suku bunga SBI mengalami penurunan serta nilai tukar rupiah mengalami penguatan, IHSG juga ikut mengalami penurunan yaitu terjadi selama bulan Maret dan Desember 2008, Maret 2011, September 2011 serta Desember 2013 Ini tentunya berlawanan dengan teori yang ada yaitu ketika inflasi dan suku bunga SBI mengalami kenaikan serta nilai tukar rupiah mengalami pelemahan maka IHSG juga ikut mengalami penurunan ataupun sebaliknya ketika inflasi dan suku bunga SBI mengalami penurunan serta nilai tukar rupiah mengalami penguatan maka IHSG juga ikut mengalami kenaikan.

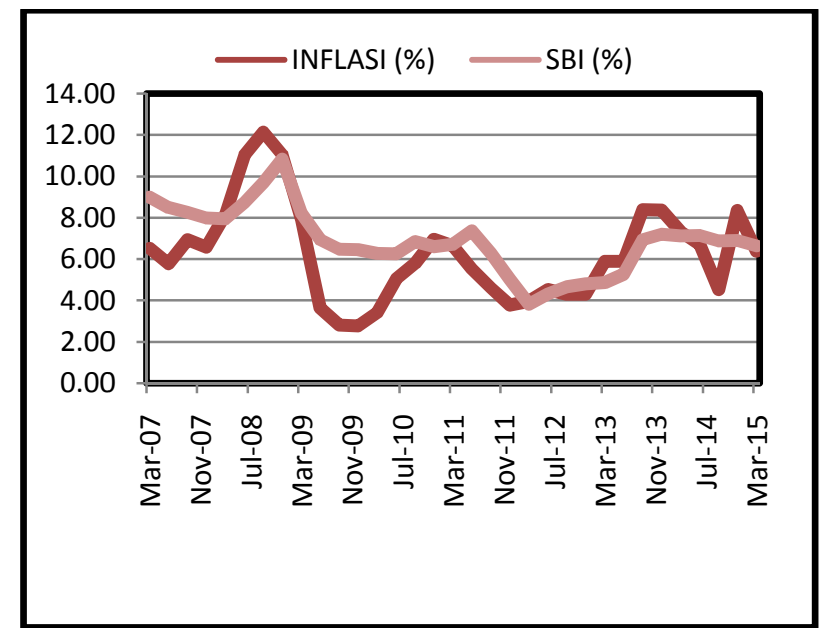

Gambar 2

Grafik Inflasi dan Suku Bunga SBI

Sumber: Data Diolah (2016) 
Tujuan dari penelitian ini adalah untuk menganalisis pengaruh inflasi, nilai tukar rupiah, dan suku bunga SBI terhadap pergerakan indeks harga saham gabungan di Bursa Efek Indonesia.

\section{B. KAJIAN TEORITIS}

Indeks harga saham gabungan merupakan nilai gabungan saham-saham perusahaan yang tercatat di Bursa Efek Indonesia yang pergerakannya mengindikasikan kondisi yang terjadi di pasar modal. Indeks harga saham gabungan akan menunjukkan pergerakan harga saham secara umum yang tercatat di Bursa Efek (Anoraga dan Pakarti, 2006: 101). Di pasar modal sebuah indeks diharapkan memiliki lima fungsi yaitu (Darmadji dan Hendi, 2012:129) :

1. sebagai indikator trend pasar,

2. sebagai indikator tingkat keuntungan,

3. sebagai tolak ukur (bench mark) kinerja suatu portofolio,

4. memfasilitasi pembentukan portofolio dengan strategi pasif, memfasilitasi berkembangnya produk derivatif.

Berubahnya indeks harga saham gabungan setiap hari karena perubahan harga pasar yang terjadi setiap hari dan adanya saham tambahan. Pergerakan IHSG secara signifikan dipengaruhi oleh pergerakan/perubahan harga-harga saham dengan kapitalisasi besar, hal itu dikarenakan IHSG menggunakan semua saham yang tercatat di BEI sebagai komponen penghitungan indeksnya sehingga perubahan pergerakan harga-harga saham dengan kapitalisasi kecil nyaris tidak berdampak pada pergerakan IHSG.

Harga saham berubah di pasar disebabkan oleh faktor permintaan dan penawaran.Variabel yang mempengaruhi permintaan dan penawaran bermacam-macam, ada yang rasional tetapi adapula yang irasional. Pengaruh yang sifatnya rasional mencakup kinerja perusahaan, tingkat bunga, tingkat inflasi, tingkat pertumbuhan, kurs valuta asing ataupun indeks harga saham dari negara lain (Samsul, 2015: 137).

Ada beberapa macam pendekatan atau metode penghitungan yang digunakan untuk menghitung indeks yaitu (Darmadji dan Hendi, 2012:131) :

1. Menghitung rata-rata (arithmetic mean) harga saham yang masuk dalam anggota indeks.

2. Menghitung (geometric mean) dari indeks individual saham yang masuk anggota indeks.

3. Menghitung rata-rata tertimbang nilai pasar (market value weighted average index).

Perhitungan indeks harga saham gabungan umumnya menggunakan metode ratarata tertimbang pasar di Bursa Efek Indonesia.

Beberapa penelitian terdahulu yang dapat dijadikan dasar dalam melakukan penelitian ini sebagai berikut:

Penelitian yang dilakukan oleh Hismendi dkk (2013) meneliti mengenai Analisis Pengaruh Nilai Tukar, SBI, Inflasi, dan Pertumbuhan GDP terhadap Pergerakan Indeks Harga Saham Gabungan di Bursa Efek Indonesia dengan hasil penelitian bahwa secara simultan Nilai Tukar, SBI, Inflasi, dan Pertumbuhan GDP berpengaruh signifikan terhadap Pergerakan IHSG sedangkan secara parsial Nilai Tukar dan SBI berpengaruh negatif, Pertumbuhan GDP berpengaruh positif dan signifikan terhadap Pergerakan IHSG serta Inflasi tidak berpengaruh signifikan terhadap pergerakan IHSG.

Krisna dan Ni Gusti (2013) meneliti mengenai Pengaruh Inflasi, Nilai Tukar Rupiah, Suku Bunga SBI pada Indeks Harga Saham Gabungan di BEI dengan hasil 
penelitian menunjukkan bahwa secara simultan Inflasi, Nilai Tukar Rupiah, dan Suku Bunga SBI berpengaruh signifikan pada IHSG sedangkan secara parsial Inflasi dan Suku Bunga SBI berpengaruh positif dan signifikan pada IHSG serta Suku Bunga SBI tidak berpengaruh signifikan pada IHSG.

Kewal (2012) melakukan penelitian mengenai Pengaruh Inflasi, Suku Bunga, Kurs, dan Pertumbuhan PDB terhadap Indeks Harga Saham Gabungan dengan hasil penelitian bahwa secara simultan Inflasi, Suku Bunga SBI, Kurs Rupiah dan Pertumbuhan PDB berpengaruh signifikan terhadap IHSG sedangkan secara parsial Kurs Rupiah berpengaruh negatif dan signifikan terhadap IHSG serta Inflasi, Suku Bunga SBI, dan Pertumbuhan PDB tidak berpengaruh signifikan terhadap IHSG.

Penelitian ini dilakukan terhadap pergerakan indeks harga saham gabungan yang merupakan bagian penting dalam pembicaraan mengkarena indeks ini merupakan indikator dari berbagai hal dan dapat dijadikan sebagai bahan pertimbangan dalam membuat kebijakan-kebijakan dibidang ekonomi. Oleh karena itu, informasi mengenai pergerakan indeks harga saham gabungan dapat membantu investor mengambil keputusan untuk berinvestasi di suatu perusahaan.

Kerangka konsep pada penelitian ini disajikan pada gambar 3.

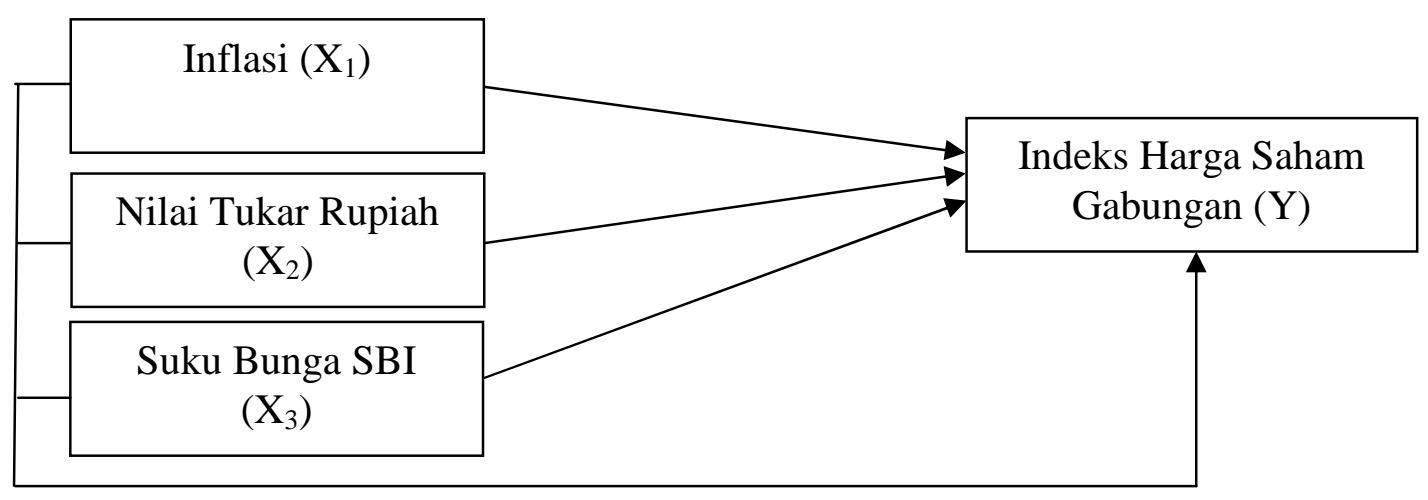

Gambar 3

Kerangka Konseptual

Pada kerangka konsep ini dijelaskan mengenai pengaruh antara variabel independen terhadap dependen dengan uraian sebagai berikut:

\section{Pengaruh Inflasi Terhadap Pergerakan Indeks Harga Saham Gabungan}

Inflasi merupakan kecenderungan meningkatnya harga-harga barang dan jasa secara umum dan terjadi dan terjadi secara terus menerus. Inflasi merupakan kenaikan harga secara terus menerus dan kenaikan harga yang terjadi pada seluruh kelompok barang dan jasa (Pohan, 2008: 6). Perubahan faktor ekonomi seperti inflasi akan mempengaruhi harga saham dengan seketika karena investor lebih cepat bereaksi. Ketika perubahan faktor makro ekonomi terjadi, investor akan mengkalkulasi dampaknya baik yang positif maupun negatif terhadap kinerja perusahaan beberapa tahun kedepan, kemudian mengambil keputusan membeli atau menjual saham yang bersangkutan. Jika investor memutuskan untuk menjual seluruh sahamnya, akibatnya harga saham akan mengalami penurunan. Hal ini juga mengakibatkan IHSG mengalami penurunan. 


\section{Pengaruh Nilai Tukar Rupiah Terhadap Pergerakan Indeks Harga Saham Gabungan}

Nilai tukar rupiah adalah harga rupiah terhadap mata uang negara lain. Misalnya nilai tukar Rupiah terhadap dollar Amerika Serikat. Excange Rates (nilai tukar uang) atau yang lebih populer dikenal dengan sebutan kurs mata uang adalah catatan (quotation) harga pasar dari mata uang asing (foreign currency) dalam harga mata uang domestik (domestic currency) atau resiprokalnya, yaitu harga mata uang domestik dalam mata uang asing (Karim, 2008: 157).

Fluktuasi nilai tukar rupiah terhadap mata uang asing akan sangat mempengaruhi iklim investasi di dalam negeri khususnya di pasar modal. Perusahaan-perusahaan di Indonesia yang sudah go public dengan masih mengandalkan bahan baku impor dari luar negeri akan menerima dampak negatif apabila mata uang rupiah terdepresiasi atau mengalami pelemahan terhadap mata uang dollar AS. Hal ini akan mengakibatkan naiknya bahan baku tersebut. Kenaikan biaya produksi akan mengurangi tingkat keuntungan perusahaan sehingga akan mendorong investor untuk melakukan aksi jual terhadap saham-saham yang dimilikinya. Apabila banyak investor yang melakukan hal tersebut, tentu akan mendorong penurunan indeks harga saham gabungan.

\section{Pengaruh Suku Bunga SBI Terhadap Pergerakan Indeks Harga Saham Gabungan}

Sertifikat Bank Indonesia (SBI) adalah surat berharga yang dikeluarkan oleh Bank Indonesia sebagai pengakuan utang berjangka waktu pendek dengan sistem diskonto/bunga. Sertifikat Bank Indonesia (SBI) adalah sekuritas atas unjuk yang diterbitkan bank sentral (Bank Indonesia) dengan nilai nominal (Manurung dan Prathama, 2004: 92).

Perubahan tingkat suku bunga SBI akan memberikan pengaruh bagi pasar modal. Apabila tingkat suku bunga naik maka secara langsung akan meningkatkan beban bunga. Perusahaan yang mempunyai leverage yang tinggi akan mendapatkan dampak yang sangat berat terhadap kenaikan tingkat bunga. Kenaikan tingkat bunga ini dapat mengurangi profitabilitas perusahaan sehingga dapat memberikan pengaruh terhadap harga saham perusahaan yang bersangkutan.

Selain kenaikan beban bunga, tingkat suku bunga SBI yang tinggi dapat menyebabkan investor tertarik untuk memindahkan dananya ke deposito. Hal ini terjadi karena kenaikan tingkat suku bunga SBI akan diikuti oleh bank-bank komersial untuk menaikkan tingkat suku bunga simpanan. Apabila tingkat suku bunga deposito lebih tinggi dari tingkat pengembalian yang diharapkan oleh investor, tentu investor akan mengalihkan dananya ke deposito.

Terlebih lagi investasi di deposito sendiri merupakan salah satu jenis investasi yang bebas resiko. Pengalihan dana oleh investor dari pasar modal ke deposito tentu akan mengakibatkan penjualan saham besar-besaran sehingga akan menyebabkan penurunan indeks harga saham.

Berdasarkan uraian diatas maka hipotesis dalam penelitian ini adalah sebagai berikut:

a. Inflasi berpengaruh negatif terhadap pergerakan indeks harga saham gabungan.

b. Nilai tukar rupiah berpengaruh negatif terhadap pergerakan indeks harga saham gabungan. 
c. Suku bunga SBI berpengaruh negatif terhadap pergerakan indeks harga saham gabungan.

d. Inflasi, nilai tukar rupiah dan suku bunga SBI berpengaruh terhadap pergerakan indeks harga saham gabungan secara simultan.

\section{A. METODOLOGI PENELITIAN}

Populasi dalam penelitian ini adalah data triwulan dari inflasi, nilai tukar rupiah, suku bunga SBI, dan indeks harga saham gabungan periode Maret 2007 s/d Maret 2015. Menggunakan data sekunder dengan metode pengumpulan data melalui dokumentasi dari situs www.bi.go.id. dan www.finance.yahoo.com.

Definisi operasional variabel dan pengukuran variabel yang digunakan pada penelitian ini adalah sebagai berikut:

1. Variabel Dependen

Indeks Harga Saham Gabungan (Y)

Indeks harga saham gabungan adalah indikator pergerakan harga saham secara umum yang tercatat BEI. Pengukuran IHSG menggunakan harga pada saat penutupan (closing price) yang telah dihitung dengan metode rata-rata tertimbang. Adapun rumusnya sebagai berikut :

$$
I H S G=\frac{\text { Kapitalisasi Pasar }}{\text { Nilai Dasar }} \times 100
$$

2. Variabel Independen

Inflasi

Inflasi adalah indikator kenaikan harga-harga barang dan jasa yang terjadi di Indonesia pada setiap bulan. Pengukuran tingkat inflasi menggunakan Indeks Harga Konsumen (IHK). Adapun rumusnya sebagai berikut :

\section{Nilai Tukar Rupiah}

$$
I n f=\frac{I H K n-I H K n-1}{I H K n-1} \times 100 \%
$$

Nilai tukar rupiah adalah adalah nilai tukar rupiah terhadap dollar AS yang menunjukkan nilai dari mata uang dollar AS yang ditranslasikan dengan mata uang rupiah. Pengukuran nilai tukar rupiah menggunakan kurs tengah rupiah.

Suku bunga SBI

Suku bunga SBI adalah suku bunga SBI yang dikeluarkan oleh Bank Indonesia sesuai Rapat Dewan Gubernur. Pengukuran suku bunga SBI menggunakan suku bunga dengan jangka waktu 1 bulan dan 9 bulan.

\section{Metode Analisis Data}

Model analisis data yang digunakan adalah regresi linear berganda yang terlebih dahulu melakukan uji asumsi klasik.

\section{Regresi Linier Berganda}

Analisis regresi berganda digunakan untuk mengetahui pengaruh inflasi, nilai tukar rupiah, dan suku bunga SBI terhadap pergerakan indeks harga saham gabungan.

Dengan persamaan regresi linear berganda sebagai berikut :

$$
\mathrm{Y}=\mathrm{a}+\mathrm{b}_{1} \mathrm{X}_{1}+\mathrm{b}_{2} \mathrm{X}_{2}+\mathrm{b}_{3} \mathrm{X}_{3}+\epsilon
$$

Dimana:

$\mathrm{Y} \quad=$ IHSG 


$$
\begin{array}{ll}
\mathrm{a} & =\text { Konstanta } \\
\mathrm{b}_{1}-\mathrm{b}_{3}= & \text { Koefisien regresi variabel } \\
& \mathrm{X}_{1}-\mathrm{X}_{3} \\
\mathrm{X}_{1}= & \text { Inflasi } \\
\mathrm{X}_{2} & =\text { Nilai Tukar Rupiah } \\
\mathrm{X}_{3}= & \text { Suku Bunga SBI } \\
\mathrm{\epsilon} & =\text { Error }
\end{array}
$$

\section{Uji Asumsi Klasik}

Pengujian asumsi klasik dalam penelitian ini adalah uji normalitas, uji multikolinieritas, uji heteroskedastisitas, dan uji autokorelasi.

\section{Uji Hipotesis}

Pengujian hipotesis dalam penelitian ini adalah uji t (t-tes), uji F (F-tes), dan uji koefisien determinasi.

\section{A. PEMBAHASAN}

Berdasarkan tabel 1 maka persamaan regresi berganda sebagai berikut: $\mathrm{IHSG}=2833.991+152.763+0.438-686.290+\epsilon$

Persamaan regresi diatas menunjukan nilai konstanta sebesar 2833.991. Koefisien regresi untuk inflasi sebesar 152.763, nilai tukar rupiah sebesar 0.438, dan suku bunga SBI sebesar -686.290.

\section{Tabel 1}

Hasil Analisis Regresi Linier

\begin{tabular}{|ll|r|c|c|c|c|}
\hline \multirow{2}{*}{ Model } & \multicolumn{2}{|c|}{$\begin{array}{c}\text { Understandardized } \\
\text { Coefficients }\end{array}$} & $\begin{array}{c}\text { Standardized } \\
\text { Coefficients }\end{array}$ & t & Sig \\
\cline { 2 - 4 } & \multicolumn{1}{|c|}{ B } & Std. Error & Beta & & \\
\hline 1 (Constant) & 2833,991 & 1099,756 & & 2,577 & 0,015 \\
& Inflasi & 152,763 & 77,801 & 0,295 & 1,964 & 0,059 \\
Nilai Tukar Rupiah & 0,438 & 0,099 & 0,470 & 4,422 & 0,000 \\
SBI & $-686,290$ & 112,718 & 0,890 & $-6,089$ & 0,000 \\
\hline
\end{tabular}

Sumber : hasil penelitian (data diolah, 2016)

\section{Uji Asumsi Klasik}

Uji asumsi klasik harus dipenuhi oleh model regresi agar tidak mengalami bias atau BLUE (Best Linear Unbiased Estimation).

\section{Uji Normalitas}

Berdasarkan Gambar 4 menunjukkan bahwa grafik Histogram berbentuk seperti lonceng dan Gambar 5 yaitu grafik Normal Probability Plots titik menyebar berhimpit disekitar diagonal maka data terdistribusi secara normal. 


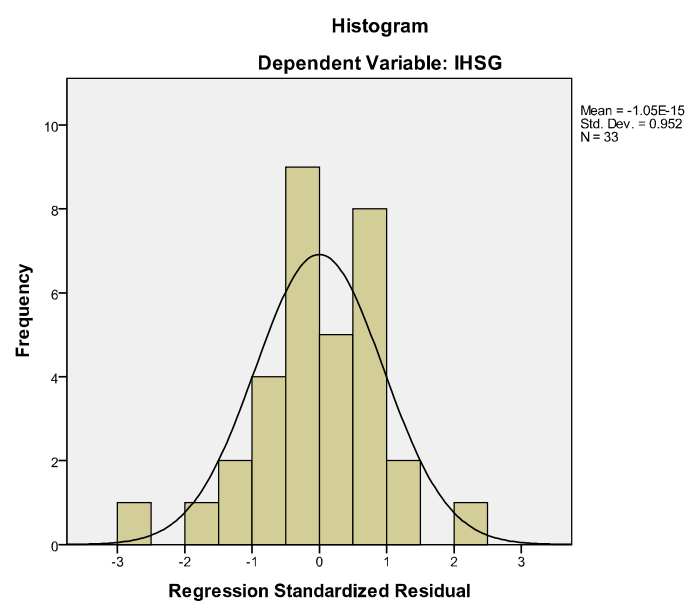

Gambar 4

Grafik Histogram

Sumber:Hasil Penelitian (Data Diolah, 2016)

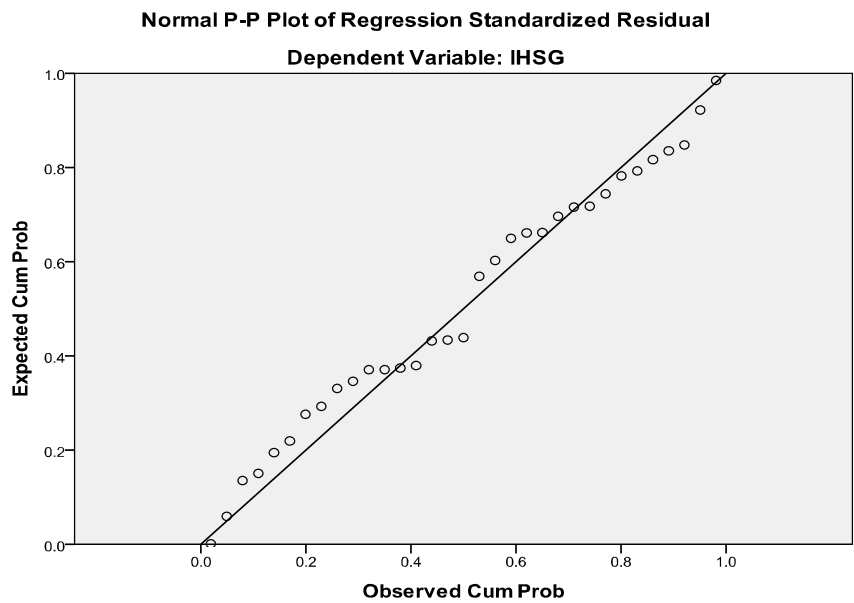

Gambar 5

Normal Probability Plots

Sumber:Hasil Penelitian (Data Diolah, 2016)

Selain itu, dapat dilihat dari hasil uji statistik melalui uji Kolmogrov-Smirnov pada Tabel 2 dengan nilai sebesar $0.973>0.05$ yang berarti bahwa data sudah terdistibusi secara normal.

Tabel 2

Uji One-Sample Kolmogorov- Smirnov

Unstandardized

Residual

\begin{tabular}{|c|c|c|}
\hline $\mathrm{N}$ & & 33 \\
\hline Normal & Mean & .0000000 \\
\hline \multirow[t]{2}{*}{ Parameters ${ }^{\mathrm{a}, \mathrm{b}}$} & Std. & 658.4518173 \\
\hline & Deviation & \\
\hline Most Extreme & Absolute & .084 \\
\hline
\end{tabular}




\begin{tabular}{lrr}
\hline Differences & Positive & .080 \\
& Negative & -.084 \\
Kolmogorov-Smirnov Z & .484 \\
Asymp. Sig. (2-tailed) & .973 \\
\hline
\end{tabular}

Sumber:Hasil Penelitian (Data Diolah, 2016)

\section{Uji Multikolinieritas}

Hasil uji statistik pada Tabel 3 dengan nilai nilai VIF masing-masing variabel lebih kecil dari 10 dan nilai tolerancenya lebih besar dari 0.10 yang berarti bahwa tidak terjadi multikolinieritas.

Tabel 3

Uji Multikolinieritas

\begin{tabular}{|l|c|c|}
\hline \multicolumn{1}{|c|}{ Model } & Collinearity Tolerance & Satistics VIF \\
\hline (Constant) & 0,460 & 2,176 \\
Inflasi & 0,922 & 1,085 \\
Nilai tukar rupiah & 0,487 & 2,055 \\
SBI & & \\
\hline
\end{tabular}

Sumber : hasil penelitian (data diolah, tahun 2016)

\section{Uji Heteroskedastisitas}

Berdasarkan Gambar 6 terlihat bahwa titik-titik menyebar secara acak baik diatas maupun dibawah angka 0 pada sumbu Y maka dapat disimpulkan

bahwa tidak terjadi heteroskedastisitas pada model regresi.

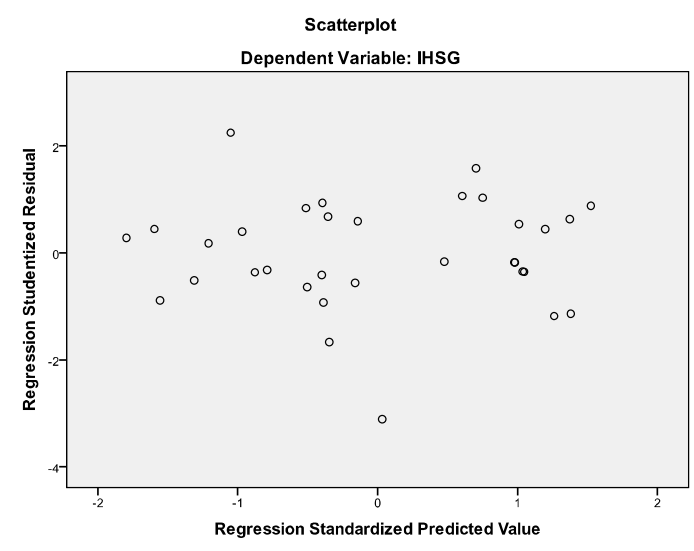

Gambar 6

Uji Heteroskedastisitas

Sumber:Hasil Penelitian (Data Diolah, 2016)

\section{Uji Autokorelasi}

Berdasarkan Tabel 4 dapat dilihat bahwa nilai Durbin Watson sebesar 0.677, berada diantara negatif 2 sampai positif 2 yang berarti tidak terjadi autokorelasi. 
Tabel 4

Uji Autokolerasi

\begin{tabular}{|c|c|c|c|c|c|}
\hline Model & $\mathrm{R}$ & $\mathrm{R}$ Square & $\begin{array}{c}\text { Adjusted R } \\
\text { Square }\end{array}$ & $\begin{array}{c}\text { Std. Error of } \\
\text { the estimate }\end{array}$ & $\begin{array}{c}\text { Durbin } \\
\text { Watson }\end{array}$ \\
\hline & 0,836 & 0,699 & 0,668 & 691,67167 & 0,677 \\
\hline
\end{tabular}

a. Predictors: (Constant), SBI, NilaiTukarRupiah, Inflasi

b. Dependent Variable: IHSG

Sumber:Hasil Penelitian (Data Diolah, 2016)

\section{Uji Hipotesis}

\section{Uji t (t-tes)}

Berdasarkan tabel 1 dapat disimpulkan sebagai berikut :

a. Inflasi berpengaruh positif dan tidak signifikan terhadap pergerakan indeks harga saham gabungan. Hal ini dapat dilihat dari tingkat signifikan sebesar 0.059 lebih besar dari dari $\alpha=0.05$ dan berarti bahwa hipotesis pertama tidak dapat diterima. Hal ini terjadi karena inflasi tidak terlalu berdampak negatif tehadap perusahaan sehingga harga saham tidak mengalami penurunan dan pada akhirnya indeks harga saham juga tidak mengalami penurunan. Hasil penelitian ini mendukung penelitian yang dilakukan oleh Hismendi dkk (2013) dan Kewal (2012).

b. Nilai tukar rupiah berpengaruh positif dan signifikan terhadap pergerakan indeks harga saham gabungan. Hal ini dapat dilihat dari tingkat signifikan sebesar 0.000 lebih kecil dari dari $\alpha=0.05$ dan berarti bahwa hipotesis kedua tidak dapat diterima. Hal ini terjadi karena sebagian perusahaan yang dominan berorientasi ekspor akan menerima dampak positif apabila nilai tukar rupiah terhadap dollar Amerika Serikat menguat sehingga harga saham akan meningkat dan pada akhirnya indeks harga saham gabungan juga meningkat. Hasil penelitian ini mendukung penelitian yang dilakukan oleh Krisna dan Ni Gusti (2013).

c. Suku bunga SBI berpengaruh negatif dan signifikan terhadap pergerakan indeks harga saham gabungan. Hal ini dapat dilihat dari tingkat signifikan sebesar 0.000 lebih kecil dari dari $\alpha=0.05$ dan berarti bahwa hipotesis ketiga dapat diterima. Hal ini terjadi karena suku bunga SBI yang tinggi dapat menyebabkan investor tertarik untuk memindahkan dananya ke deposito. Hasil penelitian ini mendukung penelitian yang dilakukan oleh Hismendi dkk (2013).

\section{Uji F (F-tes)}

Berdasarkan Tabel 5 maka inflasi, nilai tukar rupiah, dan suku bunga SBI berpengaruh signifikan terhadap pergerakan indeks harga saham gabungan secara simultan Hal ini dapat dilihat dari tingkat signifikan sebesar 0.000 lebih kecil dari dari $\alpha$ $=0.05$ dan berarti bahwa hipotesis keempat dapat diterima.

\section{Tabel 5}

Hasil Regresi Uji F

\begin{tabular}{l|l|c|c|c|c|}
\hline \multicolumn{1}{|c|}{ Model } & Sum of square & DF & Mean Square & F & Sig \\
\hline Regression & 32178450,52 & 3 & 10726150,77 & 22,420 & $0,000^{\mathrm{a}}$ \\
Residual & 13873881,46 & 29 & 478409,706 & & \\
total & 46052331,99 & 32 & & & \\
a. Predictors: (Constant), SBI, NilaiTukarRupiah, Inflasi \\
b. Dependent Variable: IHSG \\
Sumber:Hasil Penelitian (Data Diolah, 2016)
\end{tabular}




\section{Uji Koefisien Determinasi}

Berdasarkan abel 6 memperlihatkan bahwa nilai Adjusted $R$ Square sebesar 0.668 yang berarti bahwa persentase pengaruh variabel independen terhadap indeks harga saham gabungan sebesar $66.8 \%$ sedangkan sisanya $33.2 \%$ dipengaruhi atau dijelaskan oleh variabel lain yang tidak dimasukkan dalam model penelitian ini. Nilai $\mathrm{R}$ merupakan koefisien korelasi dengan nilai 0.836 atau $83.6 \%$ menunjukkan bahwa korelasi atau hubungan antara variabel independen yaitu inflasi, nilai tukar rupiah, dan suku bunga SBI dengan variabel dependen yaitu indeks harga saham gabungan adalah kuat.

\section{B. KESIMPULAN DAN SARAN}

\section{Kesimpulan}

a. Inflasi berpengaruh positif dan tidak signifikan terhadap pergerakan indeks harga saham gabungan.

b. Nilai tukar rupiah berpengaruh positif dan signifikan terhadap pergerakan indeks harga saham gabungan.

c. Suku bunga SBI berpengaruh negatif dan signifikan terhadap pergerakan indeks harga saham gabungan.

d. Inflasi, nilai tukar rupiah, dan suku bunga SBI berpengaruh signifikan terhadap pergerakan indeks harga saham gabungan secara simultan.

\section{Saran}

Berdasarkan kesimpulan dan keterbatasan diatas maka peneliti memberikan saran sebagai berikut :

a. Peneliti selanjutnya diharapkan dapat menambah variabel independen lainnya seperti variabel indeks harga saham dari negara lain sehingga dengan menambah variabel independen akan menemukan hasil penelitian baru yang diduga dapat mempengaruhi pergerakan indeks harga saham gabungan.

b. Peneliti selanjutnya diharapkan dapat menambah periode penelitian sehingga akan menemukan hasil penelitian baru yang diduga dapat mempengaruhi pergerakan indeks harga saham gabungan.

\section{DAFTAR PUSTAKA}

Anoraga, Pandji dan Piji Pakarti. (2006). Pengantar Pasar Modal. Jakarta : PT Rineka Cipta.

Darmadji, Tjiptono dan Hendi M. Fakhruddin. (2012). Pasar Modal di Indonesia. Pendekatan Tanya Jawab, Edisi 3. Jakarta : Salemba Empat.

Hismendi.; Abubakar Hamzah.; dan Said Musnadi. 2013. Analisis Pengaruh Nilai Tukar Rupiah, SBI, Inflasi dan Pertumbuhan GDP Terhadap Pergerakan Indeks Harga Saham Gabungan di Bursa Efek Indonesia. Jurnal Ilmu Ekonomi. Vol 1, No. 2: 16-28.

Karim, Adiwarman A. (2008). Ekonomi Makro Islam. Edisi Kedua. Jakarta : PT Raja Grafindo Persada.

Kewal, Suramaya Suci. 2012. Pengaruh Inflasi, Suku Bunga, Kurs, dan Pertumbuhan PDB Terhadap Indeks Harga Saham Gabungan. Jurnal Economia. Vol 8, No. 1: 53-64. 
Krisna, Anak Agung Gde Aditya dan Ni Gusti Putu Wirawati. 2013. Pengaruh Inflasi, Nilai Tukar Rupiah, Suku Bunga SBI, pada Indeks Harga Saham Gabungan di BEI. E-Jurnal Akuntansi. 3.2: 421-435.

Manurung, Mandala dan Prathama Rahardja. (2004). Uang, Perbankan, dan Ekonomi Moneter. Jakarta : Fakultas Ekonomi Universitas Indonesia (FEUI).

Pohan, Aulia. (2008). Potret Kebijakan Moneter Indonesia. Cetakan Pertama. Jakarta : PT Raja Grafindo.

Samsul, Mohamad. (2015). Pasar Modal \& Manajemen Portofolio, Edisi 2. Jakarta : Erlangga.

Situmorang M, Paulus. (2008). Pengantar Pasar Modal. Jakarta : Mitra Wacana Media 